\title{
EFFECT OF COLD STORAGE AND DIFFERENT PACKAGING MATERIALS ON THE QUALITY OF FRESH ROSEMARY HERB: II- EFFECT ON THE ESSENTIAL OIL PERCENTAGE AND COMPOSITION.
}

\author{
Abdel-Kader, H.H.; Kh.M.H. EL-Hindi.; Hekmat Y. Massoud and \\ Fatma K.Y. Badawy \\ Veget. and Flor. Dept., Fac. of Agric., Mansoura Univ.
}

\begin{abstract}
Fresh culinary herbs are one of the fastest growing markets for gourmet production on a world wide scale. Some herbs are sold fresh rather than dry because they do not retain their flavor when dried. Rosemary (Rosmarinus officinalis L.) plant is an important aromatic culinary herb. Essential oil of rosemary is considered one of the strongest natural antioxidants. A study was carried out during two successive summer seasons 2006 and 2007, at the Post Harvest Lab in the Vegt. and Floric. Dept., Fac. of Agric., Monsoura Univ.

This part (II) aimed to investigate the effect of cold storage temperatures and different packaging materials on the essential oil percentage and composition of fresh rosemary herb and the changes that took place during storage until the end of their shelf life as fresh herbs. Fresh rosemary herbs were packaged in nine different packaging materials: Butter bags (P1), Cellophane bags (P2), Nylon bags (P3), Polyethylene bags (P4), Aluminum foils (P5), Aluminum plates covered with foil (P6), Aluminum plates covered with plastic film (P7), Foam plates covered with foil (P8), Foam plates covered with plastic film (P9), and then stored at $\left(1,3\right.$, and $\left.5^{\circ} \mathrm{C}\right)$ for 6 weeks. Gas Liquid Chromatography (G.L.C.) analysis was carried out in second season summer 2007 to compare between the composition of the oil of the freshly harvested herb and the of oil of herbs packaged in Aluminum plates covered with foil (the package that gave best marketability for fresh herb shown in Part 1) after one and three weeks of storage under the three cold storage temperatures.

The results showed that the essential oil percentage of the herb increased with increasing the length of the storage period. Oil percentage in herbs stored at $3^{\circ} \mathrm{C}$ was superior to those stored under the other two temperatures in both seasons. Herbs kept in Butter bags (P1) had maximum oil percentage until the second week of storage. Cellophane bags (P2) were the highest in the fourth week of storage, while at the fifth week of storage; Foam plates covered with foil (P8) was the highest. At the end of six weeks of storage at $3 \circ \mathrm{C}$ only Aluminum plates covered with foil (P6) and Aluminum foils (P5) were marketable in both seasons, but (P6) had higher oil percentage than (P5).

GLC analysis identified 14 compounds constituted $88.8 \%$ of the essential oil of rosemary fresh herb after harvest (control). The identified compounds included seven hydrocarbons forming $57.25 \%$ and seven oxygenated forming $31.55 \%$ of the total compounds. Hydrocarbons were $\alpha$ - pinene $(11.93 \%), \beta$ - pinene $(7.01 \%)$, limonene (3.01\%), $\rho$ - cymene $(10.11 \%)$, camphene $(7.94 \%)$, $\gamma$ - terpinene $(9.23 \%)$, and $\alpha$ - terpinolene (8.02\%). Oxygenated compounds were 1,8 cineole $(7.27 \%)$, linaloo $(6.79 \%)$, verbenol (1.94 \%), borneol (3.83\%), thymol (4.47\%), camphor $(2.3 \%)$, and terpineol $(4.95 \%)$. The total percentage of hydrocarbons and oxygenated compounds decreased after storage compared with the control. The total percentage of each of hydrocarbons and oxygenated compounds were higher at $3^{\circ} \mathrm{C}$ than those at either 1 or $5^{\circ} \mathrm{C}$ at the two comparable storage periods. At a storage temperature of $3^{\circ} \mathrm{C}$, all hydrocarbons had higher percentages after one week of storage than after three
\end{abstract}


Abdel-Kader, H.H. et al.

weeks of storage, except for $\beta$-pinene and limonene, while all oxygenated compounds had higher percentages after three weeks of storage than after one week of storage, except for thymol and terpineol.

\section{INTRODUCTION}

Rosemary, Rosmarinus officinalis L., Fam. Lamiaceae (Labiateae), is a common plant of the Mediterranean coastland, Portugal, and Spain (Keville, 1999). The prime effectiveness of this herb is culinary rather than medicinal. As a medicinal herb, it has been considered a digestion aid, an astringent, a diaphoretic, and a tonic (Chiej, 1984).

The oil of rosemary is found in the leaves and flowers, and its yield varies from about $0.725 \%$ in summer to $0.435 \%$ in winter. The components of rosemary oil are $\alpha$-pinene, $\beta$-pinene, limonene, cineole, camphor, borneol, $\rho$-cymene, linalool, terpineol- $40 \mathrm{ol}$ and caryophellene (Panda, 2000).

Giese (1994) reported that the chief sources of flavor in many spices are oils that volatilize at low temperatures. Most spices contain between 0.5 and $3.0 \%$ volatile oils. Mae (2004) mentioned that essential oils are volatile at room temperature and will eventually evaporate, and that when a ground spice is exposed to air, bright light or heat, the concentration of oil is diminished and the spice looses its flavoring ability.

Herbs can be packaged in bags designed to minimize water loss and store refrigerated (Bhide, 2006). When herbs are packaged this way, it is particularly important to maintain constant temperatures, to reduce condensation inside the bag and the consequent risk of fungal or bacterial growth (Cantwell, 1992). Most fresh herbs of the Labiate's family keep well when packed in cartons lined with folded perforated polyethylene (PE), in which water loss, leaf abscission and decay are minimal (Aharoni et al., 1993). The salad mix contained the leafy herbs was stored at $0^{\circ} \mathrm{C}, 5^{\circ} \mathrm{C}$, or $10^{\circ} \mathrm{C}$ for 14 days in perforated or non perforated BOPP bags (Tomkins and Chennel, 2000). Lamberti and Escher (2007) reported that Aluminum foils is an important material in laminates and has wide application in food packaging. Its barrier function against the migration of moisture, oxygen and other gases, and volatile aroma, as well as against the impact of light is generally higher than any plastic laminate material.

The length of storage affected the essential oil content and composition of many medicinal and aromatic plants (Baritaux et al., 1992). These changes depend on condition of plant material, method and conditions of drying and storage (i.e. temperature and humidity), (Joyce and Reid, 1986), and the chemical composition of the essential oil (Paakkonen et al., 1990). Singh et al. (1994) also reported that the storage period length affected the percentage of Cymbopogon essential oil and the relative percentages of its constituents.

Most herbs such as thyme, oregano, rosemary, sage, mint, and marjoram retain good visual quality after being held up to 4 weeks at $0^{\circ} \mathrm{C}$., while basil suffers from chilling injury, including loss of flavor, after 5 to 7 days at $7.5^{\circ} \mathrm{C}$, and after only 2 days at $2^{\circ} \mathrm{C}$ (Cantwell and Reid 1993). Kmiecik et al. (2001) found that the content of volatile oil of dill was reduced by $53-55 \%$ after 
14 days of storage in the cold room at $1 \stackrel{\circ}{\circ}$. Xuetong and Sokorai (2002) mentioned that the most amount of aldehydes in fresh cilantro leaves oil (Coriandrum sativum L.) peaked at 3 days and then decreased afterward during storage at $3^{\circ} \mathrm{C}$.

The objective of this study was to investigate the impact of cold storage on production of essential compounds after packing in different packing materials as well as during a 6 weeks storage periods.

\section{MATERIALS AND METHODS}

The present study was carried out at the Post harvest lab in the Veget. and Flor. Dept., Fac. of Agric Monsoura Univ. during two successive summer seasons (2006) and (2007).

Plant samples of Rosemarinus officinals L., (rosemary) were taken from mother plants grown in the Medicinal and Aromatic Plants Farm. Rosemary plants were harvested on the first week of July in both seasons. Early in the morning and before harvesting, plants were gently washed in the field with a water hose to remove the field dust off the plants. Two hours later, plants were harvested by cutting the herb $10 \mathrm{~cm}$ above soil surface without bruising or injuring the leaves and stems. The cut herbs were carried to the lab and placed on tissue paper for one hour to cool down and fanning before storage. Five samples were taken randomly from the leaves for oil percentage determination at the time of harvest (control). Fresh herb samples $(50 \mathrm{~g}$ each) were weighed and packaged in nine different packaging materials:

1-Butter bags (P1). 2-Cellophane bags (P2).

4-Polyethylene bags (P4). 5- Aluminum foils (P5)

3-Nylon bags (P3)

6- Aluminum plates covered with foil (P6)

7- Aluminum plates covered with plastic film (P7)

8- Foam plates covered with foil (P8)

9- Foam plates covered with plastic film (P9)

The first four treatment (P1, P2, P3, and P4), bags were perforated to airing. As mentioned in Part 1, the different packages were divided into four groups; the first group was left in the lab at room atmosphere, while the other three groups were placed inside refrigerators and stored at three different temperatures $\left(1,3\right.$ and $\left.5^{\circ} \mathrm{C}\right)$. The samples were examined every week until the end of the shelf life of the herb. In Part 1, during weight loss of herb and chlorophyll content were measured weekly for comparison with control samples which left at room atmosphere storage periods. In this Part, the essential oil percentage was first determined for the fresh herb immediately after harvest (control), and later each week for the herbs placed in cold storage until the end of the shelf life of all packages. Essential oil components were measured initially (immediately after packing) in the fresh samples, and later after $1^{\text {st }}$ and $3^{\text {rd }}$ week of storage. 
Data recorded:

1- Essential oil percentage (\%): Every week, five plant samples were randomly taken from each packaging material under each cold storage temperature $\left(1,3\right.$ and $5{ }^{\circ} \mathrm{C}$ ) (total 15 samples for each package), the essential oil was extracted from the fresh plant samples $(50 \mathrm{~g})$ by hydrodistillation using Clevenger apparatus according to methods described by the Egyptian pharmacopoeia (1984). The essential oil percentage was determined for each different package under different storage temperatures weekly after storage until the end of the shelf-life of each treatment.

2- Gas Liquid Chromatography (G.L.C.): In the second season, based on the results of shelf life of the two seasons. The oil of fresh herbs packaged in Aluminum plates covered with foil $\mathbf{P 6}$ stored in $\left(1,3\right.$ and $\left.5{ }^{\circ} \mathrm{C}\right)$ after one and three weeks of storage, in addition to the oil of the fresh control herb were subjected to GLC analysis at the Central Laboratory of Cairo Univ. The relative retention time (RT) of each peak was compared with the reference authentic sample to identify the unknown samples. The quantitative estimation for each component was based on the peak area measurement by triangulation (Guenther and Joseph, 1978).

\section{Experimental design}

The experimental design was factorial experiment in complete randomized blocks design with three replicates, each replicate contained fifteen packages. All the plants stored inside nine different storage materials at three cold temperatures $(1,3$ and $5 \mathrm{C})$ for 6 weeks storage periods.

\section{Statistical analysis:}

Data of the present study were statistically analyzed and the differences between the means of the treatments were considered significant when they were more than least significant differences (L.S.D) at the levels of 5\% according to Gomez and Gomez (1984).

\section{RESULTS AND DISCUSSION}

\section{Effect of cold storage and packaging materials and their interactions on the essential oil percentage (\%) of rosemary herb:}

\section{Effect of storage temperature:}

Figure (1) show the changes in oil percentages of the herb stored at three cold temperatures $\left(1,3\right.$, and $\left.5{ }^{\circ} \mathrm{C}\right)$ throughout the storage period regardless of the type of packaging material. It is clear that increasing the storage period resulted in an increase in the oil percentage under the three storage temperature. This might be related to the fresh weight loss that takes place in herbs due to increasing the storage period, and thus increases the percentage of the essential oil. It is also obvious that the oil \% in herbs stored at $3{ }^{\circ} \mathrm{C}$ was superior and increased more than those stored under the other two temperatures in both seasons. It was demonstrated in Part 1 of this research that herbs stored at $3{ }^{\circ} \mathrm{C}$ loses more weight than those stored at either $1^{\circ} \mathrm{C}$ or $5^{\circ} \mathrm{C}$. 


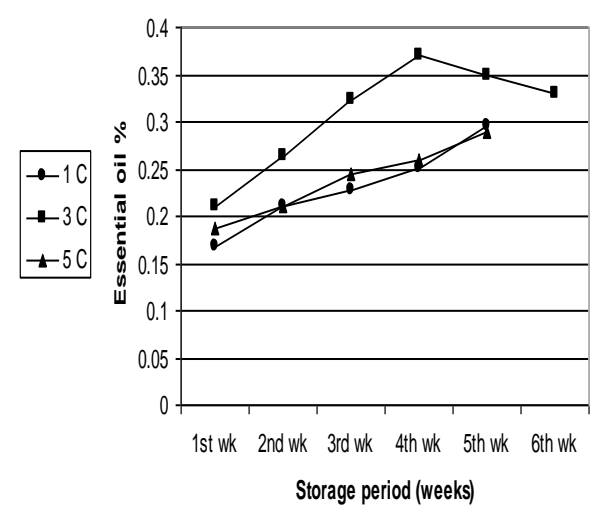

First season

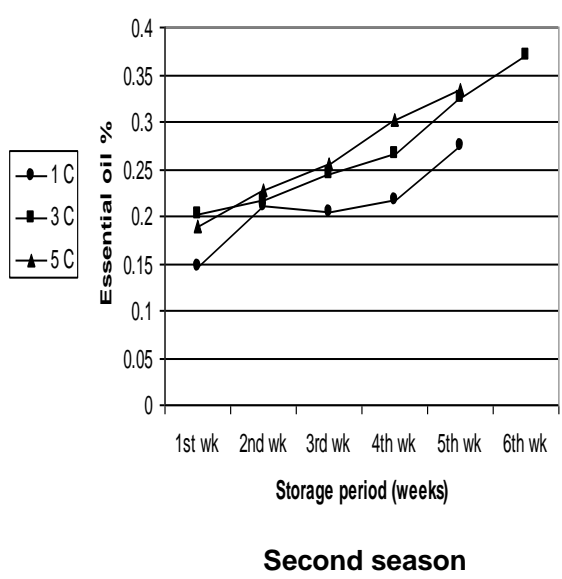

Second season

Figure (1): Essential oil percentage (\%) of rosemary fresh herbs stored at $\left(1,3\right.$ and $\left.5{ }^{\circ} \mathrm{C}\right)$ during their shelf-life in the first and second seasons (2006 \& 2007).

\section{Effect of packaging material:}

Figures (2\&3) show the changes in oil percentages of the herbs packaged in different packaging materials stored throughout the storage period regardless of the storage temperature. The figures show that oil percentage of the herb increased with increasing the length of the storage period. This is due to the decrease in fresh weight of the herb with increasing the storage period by losing water from the packages as demonstrated in Part 1 of this research. In this concern, Bhide (2006) reported that herbs can be packaged in bags designed to minimize water loss and store refrigerated. Data also show that in both seasons, herbs kept in Butter bags (P1) had maximum oil percentage until the second week of storage. This is due to the fact, which was demonstrated in Part 1, that (P1) was the least package to maintain the fresh weight of the herb, and dried out after the second week of storage. Cellophane bags (P2) were the highest in the fourth week of storage, while at the fifth week of storage, Foam plates covered with foil (P8) was the highest followed by Aluminum plates covered with foil (P6), Polyethylene bags (P4), and Aluminum foils (P5). At the end of six weeks of storage, only two packages (P6 \& P5), in addition to P8 in the second season were marketable as fresh herbs. In the first season, P6 had higher oil \% than P5, while in the second season; P8 had higher oil percentage than P6 or P5. These results are mainly due to the capacity of each package to maintain the fresh weight of the herb, along with other factors like the differences in gas exchange capacity between packages which might lead to lose oil by oxidation or evaporation. However, it worth to mention here that P5 and P6 used Aluminum foils. This is in accordance with Lamberti and Escher (2007), who reported that Aluminum foil is an important material in laminates and has wide applications in food packaging. It has a barrier function against the migration of moisture, oxygen and other gases, and volatile aroma. 


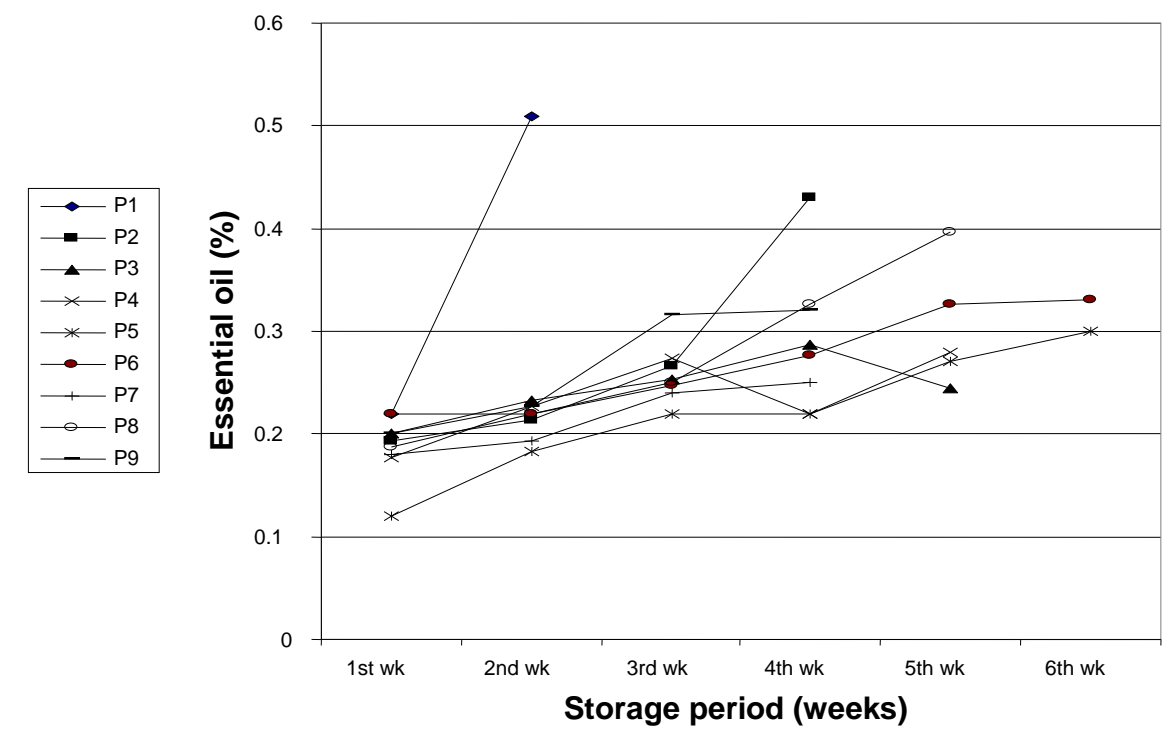

Fig. (2): Essential oil (\%) of rosemary fresh herbs in different packaging materials* during their shelf-life in the first season (2006).

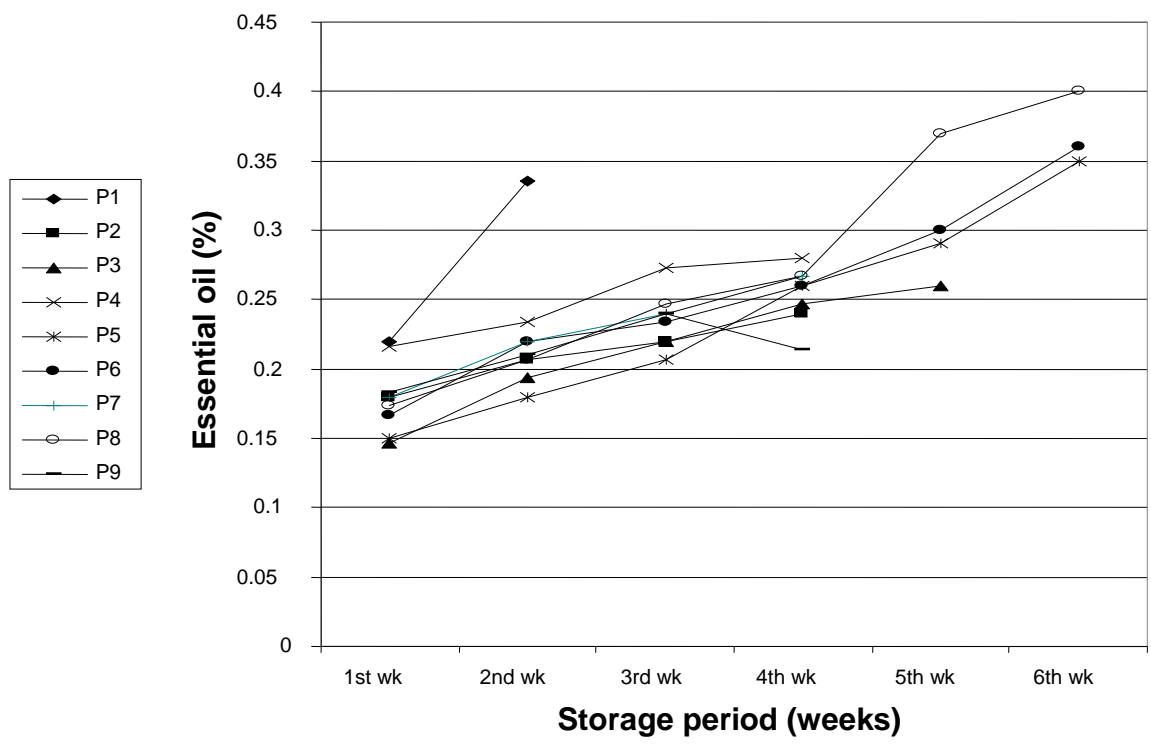

Fig. (3): Essential oil (\%) of rosemary fresh herbs in different packaging materials* during their shelf-life in the second season (2007).

* Butter bags (P1)

Cellophane bags (P2)

Nylon bags (P3)

Polyethylene bags (P4) Aluminum foil (P5)

Aluminum plates covered with foil (P6) Aluminum plates covered with plastic film (P7)

Foam plates covered with foil (P8)

Aluminum plates covered with plastic film (P
Foam plates covered with plastic film (P9) 
3. Effects of interaction between cold storage and packaging materials:

Results in Table (1) show that the essential oil percentage of rosemary fresh herb was significantly affected by the using of packaging materials at the cold storage temperatures $\left(1,3\right.$ and $\left.5^{\circ} \mathrm{C}\right)$ through 6 weeks storage period. Although the Butter bags (P1) stored at $1^{\circ} \mathrm{C}$ at produced maximum significant essential oil percentage $(0.4 \%)$ in both seasons compared with other packages, the shelf life of the herbs ended earlier since they dried out and were not marketable for fresh market after two weeks only of storage. This package was the best one for oil percentage if sold within two weeks of cold storage. After 3 weeks of storage, the herbs packaged in Polyethylene bags (P4) and stored at $3{ }^{\circ} \mathrm{C}$ had the highest oil percentage $(0.38 \%)$ in both seasons, but they also were marketable for fresh market for three weeks. However, not all compounds of each group respond in a similar way, since at $3^{\circ} \mathrm{C}$ all hydrocarbons had higher percentages after one week of storage than after three weeks of storage, except for $\beta$ - pinene and limonene, while all oxygenated compounds had higher percentages after 3 weeks of storage than after one week of storage, except for thymol and terpineol.

Table (1). Essential oil percentage (\%) of rosemary fresh herb as affected by packing materials at 1,3 and $5{ }^{\circ} \mathrm{C}$ storage temperature through 6 weeks storage period in the two summer seasons of 2006 and 2007.

\begin{tabular}{|c|c|c|c|c|c|c|c|c|c|c|c|c|c|}
\hline \multirow{3}{*}{$\begin{array}{l}\text { Packaging } \\
\text { material }\end{array}$} & \multirow{3}{*}{$\begin{array}{l}\text { Storage } \\
\text { Temp } \\
{ }^{\circ} \mathrm{C}\end{array}$} & \multicolumn{12}{|c|}{ Storage periods (weeks) } \\
\hline & & \multicolumn{6}{|c|}{$1^{\text {st }}$ season } & \multicolumn{6}{|c|}{$2^{\text {nd }}$ season } \\
\hline & & 1 & 2 & 3 & 4 & 5 & 6 & 1 & 2 & 3 & 4 & 5 & 6 \\
\hline \multirow{3}{*}{$\begin{array}{l}\text { Butter bags } \\
\text { (P1) }\end{array}$} & 1 & 0.26 & 0.40 & & & & & 0.24 & 0.42 & & & & \\
\hline & 3 & 0.24 & 0.40 & & & & & 0.22 & 0.40 & & & & \\
\hline & 5 & 0.16 & 0.22 & & & & & 0.17 & 0.25 & & & & \\
\hline \multirow{3}{*}{$\begin{array}{c}\text { Cellophane bags } \\
\text { (P2) }\end{array}$} & 1 & 0.20 & 0.20 & 0.21 & 0.22 & 0.23 & & 0.16 & 0.20 & 0.22 & 0.23 & 0.30 & \\
\hline & 3 & 0.20 & 0.24 & 0.36 & & & & 0.20 & 0.22 & 0.22 & & & \\
\hline & 5 & 0.18 & 0.20 & 0.24 & 0.24 & 0.37 & & 0.18 & 0.20 & 0.22 & 0.26 & 0.34 & \\
\hline \multirow{3}{*}{$\begin{array}{l}\text { Nylon bags } \\
\text { (P3) }\end{array}$} & 1 & 0.20 & 0.22 & 0.23 & 0.24 & 0.25 & & 0.12 & 0.16 & 0.20 & 0.21 & 0.24 & \\
\hline & 3 & 0.22 & 0.26 & 0.30 & 0.38 & & & 0.16 & 0.22 & 0.22 & 0.26 & & \\
\hline & 5 & 0.18 & 0.22 & 0.24 & 0.24 & 0.25 & & 0.16 & 0.20 & 0.24 & 0.28 & 0.28 & \\
\hline \multirow{3}{*}{$\begin{array}{l}\text { Polyethylene } \\
\text { bags } \\
\text { (P4) }\end{array}$} & 1 & 0.17 & 0.20 & 0.22 & 0.23 & 0.30 & & 0.16 & 0.18 & 0.20 & 0.24 & 0.30 & \\
\hline & 3 & \begin{tabular}{|l|}
0.20 \\
\end{tabular} & 0.30 & \begin{tabular}{|l|}
0.38 \\
\end{tabular} & & & & 0.30 & 0.31 & 0.38 & & & \\
\hline & 5 & 0.16 & 0.18 & 0.22 & 0.22 & 0.26 & & 0.19 & 0.22 & 0.24 & 0.30 & 0.36 & \\
\hline \multirow{3}{*}{$\begin{array}{l}\text { Aluminum foils } \\
\text { (P5) }\end{array}$} & 1 & 0.12 & 0.15 & 0.20 & 0.20 & 0.23 & & 0.18 & 0.20 & 0.22 & 0.23 & 0.26 & \\
\hline & 3 & 0.12 & 0.22 & 0.24 & 0.24 & 0.30 & 0.30 & 0.12 & 0.14 & 0.20 & 0.24 & 0.32 & 0.35 \\
\hline & 5 & 0.12 & 0.18 & 0.22 & 0.22 & & & 0.15 & 0.20 & 0.20 & 0.24 & & \\
\hline \multirow{3}{*}{\begin{tabular}{|c|}
$\begin{array}{c}\text { Aluminum plates } \\
\text { covered with foil } \\
\text { (P6) }\end{array}$ \\
\end{tabular}} & 1 & 0.20 & 0.21 & 0.24 & 0.30 & & & 0.10 & 0.20 & 0.21 & 0.22 & & \\
\hline & 3 & 0.24 & 0.25 & 0.26 & 0.28 & 0.30 & 0.33 & 0.20 & 0.22 & 0.24 & 0.26 & 0.30 & 0.36 \\
\hline & 5 & 0.22 & 0.22 & 0.24 & 0.30 & & & 0.20 & 0.24 & 0.26 & 0.30 & & \\
\hline \multirow{3}{*}{\begin{tabular}{|c|} 
Aluminum plates \\
covered with \\
plastic film (P7)
\end{tabular}} & 1 & 0.11 & 0.13 & 0.22 & 0.25 & & & 0.12 & 0.20 & 0.21 & 0.22 & & \\
\hline & 3 & 0.22 & 0.24 & 0.26 & 0.26 & & & 0.18 & 0.18 & 0.22 & 0.24 & & \\
\hline & 5 & 0.22 & 0.23 & 0.24 & 0.36 & & & 0.20 & 0.24 & 0.28 & 0.32 & & \\
\hline \multirow{3}{*}{$\begin{array}{l}\text { Foam plates } \\
\text { covered } \\
\text { with foil (P8) }\end{array}$} & 1 & 0.11 & 0.20 & 0.25 & 0.28 & 0.39 & & 0.10 & 0.16 & 0.20 & 0.21 & 0.32 & \\
\hline & 3 & 0.24 & 0.25 & 0.26 & 0.40 & 0.46 & & 0.22 & 0.23 & 0.24 & 0.26 & 0.38 & 0.40 \\
\hline & 5 & 0.22 & 0.22 & 0.24 & 0.30 & 0.34 & & 0.20 & 0.24 & 0.30 & \begin{tabular}{|l|} 
\\
\end{tabular} & 0.36 & \\
\hline \multirow{3}{*}{$\begin{array}{c}\text { Foam plates } \\
\text { covered with } \\
\text { plastic film (P9) }\end{array}$} & 1 & 0.16 & 0.20 & 0.27 & 0.30 & & & 0.14 & 0.18 & 0.20 & 0.22 & & \\
\hline & 3 & 0.22 & 0.24 & 0.26 & & & & 0.18 & 0.20 & 0.22 & & & \\
\hline & 5 & 0.22 & 0.24 & \begin{tabular}{|l|}
0.32 \\
\end{tabular} & \begin{tabular}{|l|}
0.34 \\
\end{tabular} & & & 0.23 & 0.25 & 0.30 & 0.32 & & \\
\hline \multicolumn{2}{|l|}{ L.S.D 5\% } & 0.016 & 0.019 & 0.019 & 0.017 & U. & & 0.016 & 0.019 & 0.019 & 0.01 & & 0.016 \\
\hline
\end{tabular}


These results are in agreement with Joyce and Reid (1986), Paakkonen et al. (1990) and Baritaux et al. (1992) who reported that the length of storage affected the essential oil content and composition of many medicinal and aromatic plants,. Also Singh et al. (1994) reported that the storage period length affected the percentage of Cymbopogon essential oil and the relative percentages of its constituents.Among the herbs that were marketable for fresh market for five weeks, were those packaged in Foam plates covered with foil (P8) since they had the highest oil \% in both seasons $(0.46 \%$ and $0.38 \%$ in the first and second seasons respectively). However, after 6 weeks of storage, only two packages stored at $3{ }^{\circ} \mathrm{C}$ in both seasons were marketable for fresh herb market; Aluminum foils (P5) and Aluminum plates covered with foil (P6). The former had $0.3 \%$ and $0.35 \%$ oil in the first and second season respectively, and the later had $0.33 \%$ and $0.36 \%$ oil in the same respective order. In the same concern, Joyce and Reid (1986), reported that length of the storage period of plant materials and cold storage affected the percentage and composition of their essential oil, and these changes depend on condition of plant material, method and condition of storage (i.e temperature and packing materials). Aluminum foil would act as barrier against the migration of moisture, oxygen and other gases, and volatile aroma, as previously mentioned by Lamberti and Escher (2007). Results of Part I showed that Aluminum foil seemed to improve the shelf life through creating a modified atmosphere inside the package that would lead to delaying senescence of the herb, and those results are in accordance with Aharoni et al. (1989) on dill and coriander, Gomez et al. (1999) on coriander, Rashed (2002) on dill, coriander and parsley. The increase of storage periods and the increase in oil percentage at cooling storage by using different storage materials may be attributed to the fresh weight loss by long storage. Similar results were obtained by Al-Kershi (2003) on sweet basil and spearmint and Karwowska (1997) on fresh basil and tarragon. It worth to mention that, although other packages had high oil percentage in earlier weeks of storage, since Aluminum foils (P5) and Aluminum plates covered with foil (P6) were the two packages that maintained reasonable oil percentage until the end of the longest storage period in the two seasons.

II. Effect of cold storage on the essential oil constituents (\%) of rosemary fresh herb packaged in Aluminum plates covered with aluminum foil after one and three weeks of storage:

Data in Table (2) and illustrated in Figure (4) show that 14 compounds constituted $88.8 \%$, were identified in the essential oil of rosemary fresh herb after harvest (control). The identified compounds could be divided into seven hydrocarbons forming $57.25 \%$ and seven oxygenated forming $31.55 \%$ of the total compounds. Hydrocarbons were $\alpha$ - pinene $(11.93 \%), \beta$ - pinene $(7.01$ $\%)$, limonene $(3.01 \%), \rho$ - cymene $(10.11 \%)$, camphene $(7.94 \%), \quad y$ terpinene $(9.23 \%)$, and $\alpha$ - terpinolene $(8.02 \%)$. Oxygenated compounds were 1,8 cineole $(7.27 \%)$, linalool $(6.79 \%)$, verbenol $(1.94 \%)$, borneol $(3.83 \%)$, thymol $(4.47 \%)$, camphor $(2.3 \%)$, and terpineol $(4.95 \%)$. Very similar results were mentioned by Panda, (2000), who reported that the components of rosemary oil included $\alpha$ - pinene, $\beta$ - pinene, limonene, $\rho$ - cymene, myrcene, cineol, linalool, borneol, and terpineol along with other three different compounds that were not found in our analysis.

In general, the total percentage of hydrocarbons and oxygenated compounds decreased after storage compared with the control. Results also 
show that storage period from one to decreased after storage compared with the control. three weeks affected oil composition in a contradicting way.

The total hydrocarbons percentage decreased as the storage period increased from one week to three weeks in all comparable storage temperatures, while the total oxygenated compounds percentages increased as the storage period increased from one to three weeks.

It is very likely that the environment within the package changes during storage creating a modified atmosphere that would affect the each constituent of the oil in a different way depending on the chemical composition of a specific constituent. The storage temperature also affected the total percentages of hydrocarbons and oxygenated compounds. The total percentage of each of hydrocarbons and oxygenated compounds were higher at $3{ }^{\circ} \mathrm{C}$ than those at either $1^{\circ} \mathrm{C}$ or $5^{\circ} \mathrm{C}$ at the two comparable storage periods. The results are in accordance with Cantwell and Reid (1993), who indicated that most herbs such as thyme, oregano, rosemary, sage, mint, and marjoram retain good visual quality after being held up to 4 weeks at $0{ }^{\circ} \mathrm{C}$, while basil suffers from chilling injury, including loss of flavor, after 5 to 7 days at $7.5^{\circ} \mathrm{C}$, and after only 2 days at $2^{\circ} \mathrm{C}$.

However, not all compounds of each group respond in a similar way, since at $3^{\circ} \mathrm{C}$ all hydrocarbons had higher percentages after one week of storage than after three weeks of storage, except for $\beta$ - pinene and limonene, while all oxygenated compounds had higher percentages after 3 weeks of storage than after one week of storage, except for thymol and terpineol.

Table (2). The principal components percentage (\%) of rosemary essential oil of the fresh control herb and of Aluminum plates covered with foil affected by three cold storage temperatures after the $1^{\text {st }}$ and $3^{\text {rd }}$ week of storage period in the second summer season (2007).

\begin{tabular}{|c|c|c|c|c|c|c|c|}
\hline \multirow{3}{*}{$\begin{array}{c}\text { Components } \\
(\%)\end{array}$} & \multirow{3}{*}{ Control } & \multicolumn{6}{|c|}{ Cold storage temperature ( ${ }^{\circ} \mathrm{C}$ ) Storage periods (weeks) } \\
\hline & & \multicolumn{2}{|c|}{$1^{\circ} \mathrm{C}$} & \multicolumn{2}{|c|}{$3^{\circ} \mathrm{C}$} & \multicolumn{2}{|c|}{$5^{\circ} \mathrm{C}$} \\
\hline & & $1^{\text {st }}$ week & $3^{\text {rd }}$ week & $1^{\text {st }}$ week & $3^{\text {rd }}$ week & $1^{\text {st }}$ week & $3^{\text {rd }}$ week \\
\hline \multicolumn{8}{|c|}{ Hydrocarbon compounds } \\
\hline 1. $\alpha$ - pinene & 11.93 & 8.76 & 8.37 & 10.42 & 9.93 & 9.59 & 8.93 \\
\hline 2. $\beta$-pinene & 7.01 & 1.99 & 3.35 & 3.94 & 4.83 & 2.97 & 4.09 \\
\hline 3. limonene & 3.01 & 1.20 & 1.99 & 1.88 & 3.56 & 1.50 & 2.78 \\
\hline 4. $\rho$ - cymene & 10.11 & 10.10 & 6.96 & 9.27 & 7.45 & 8.44 & 7.20 \\
\hline 5. camphene & 7.94 & 8.71 & 6.77 & 9.17 & 8.89 & 8.94 & 7.83 \\
\hline 6. $\mathrm{y}$ - terpinene & 9.23 & 10.23 & 4.45 & 10.32 & 7.69 & 11.31 & 6.07 \\
\hline 7. $\alpha$ - terpinolene & 8.02 & 11.74 & 11.68 & 11.89 & 9.89 & 12.82 & 10.79 \\
\hline Total hydrocarbons & 57.25 & 52.73 & 43.57 & 56.89 & 52.24 & 55.57 & 47.69 \\
\hline \multicolumn{8}{|c|}{ Oxygenated compounds } \\
\hline 8. 1,8 cineole & 7.27 & 0.74 & 1.45 & 2.13 & 4.40 & 1.44 & 2.92 \\
\hline 9. linalool & 6.79 & 1.98 & 3.87 & 5.09 & 8.34 & 3.54 & 6.41 \\
\hline 10. verbenol & 1.94 & 1.45 & 2.64 & 1.75 & 2.78 & 1.60 & 2.49 \\
\hline 11. borneol & 3.83 & 2.40 & 4.98 & 5.21 & 6.23 & 3.81 & 5.60 \\
\hline 12. thymol & 4.47 & 7.22 & 4.75 & 6.14 & 3.67 & 5.06 & 3.97 \\
\hline 3. camphor & 2.3 & 0.69 & 1.78 & 1.75 & 1.91 & 0.72 & 1.99 \\
\hline 14. Terpineol & 4.95 & 5.07 & 3.11 & 3.37 & 2.24 & 4.47 & 2.17 \\
\hline Total oxygenated & 31.55 & 19.55 & 22.58 & 25.44 & 29.57 & 20.64 & 25.55 \\
\hline known & 88.8 & 72.28 & 66.15 & 82.33 & 81.81 & 76.21 & 73.24 \\
\hline
\end{tabular}



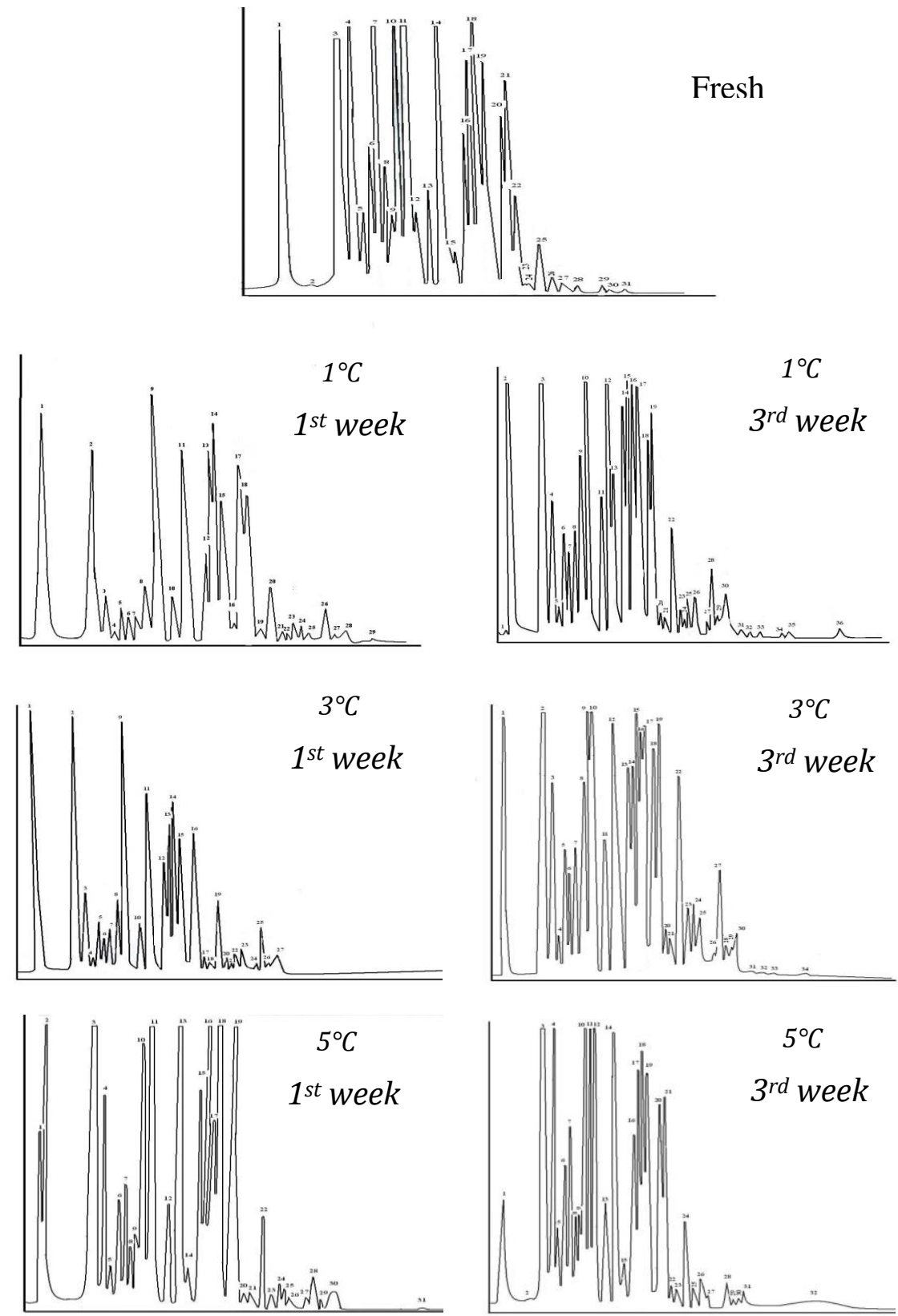

Fig. (4): GLC chromatography of rosemary essential oil components (\%) of the fresh control herb and of Aluminum plates covered with foil affected by three cold storage temperatures after the $1^{\text {st }}$ and $3^{\text {rd }}$ week of storage period in the second summer season (2007). 
These results are in agreement with Joyce and Reid (1986), Paakkonen et al. (1990) and Baritaux et al. (1992) who reported that the length of storage affected the essential oil content and composition of many medicinal and aromatic plants,. Also Singh et al. (1994) reported that the storage period length affected the percentage of Cymbopogon essential oil and the relative percentages of its constituents.

According to the fore mentioned results, it could be recommended that, the end of six weeks of storage at $3 \circ \mathrm{C}$ only Aluminum plates covered with foil (P6) and Aluminum foils (P5) were marketable in both seasons, but (P6) had higher oil percentage than (P5). The total percentage of each of hydrocarbons and oxygenated compounds were higher at $3^{\circ} \mathrm{C}$ than those at either 1 or $5^{\circ} \mathrm{C}$ at the two comparable storage periods.

\section{REFERENCES}

Aharoni, N; A. Reuveni, and O. Dvir (1989). Modified atmospheres in film packages delay senescene and decay of green vegetable and herbs. Acta Hort. 258: 255-262.

Aharoni, N.; O. Dvir; D. Chalupowicz and Z. Aharon (1993). Coping with postharvest physiology of fresh culinary herbs, Acta Hort: 344: 69-78.

Al-Kershi, A. G. (2003). Post harvest packaging and temperature controlled storage of spearmint and sweet basil herbs destined for medicinal and aromatic uses. Ph. D. Thesis, Fac.Agric., Alex. Univ., Egypt

Baritaux, O.; H. Rchard; J. Touche and M. Derbesy (1992). Effect of drying and storage of herbs and speices on the essential oil. Part I. Basil Ocimum basillicum L. Flavour and Fragrance J., 7(5): 267-271.

Bhide, M. (2006). Buying, using and storing their favorite spices and herbs, Cookbook, ISBN:0-9640514-1-9, Kathy Casey.

Cantwell, M. (1992). Handling of Fresh Culinary Herbs. Postharvest specialist, Small Farm News. California Univ. http:// www. Postharvest.

Cantwell, M. and M. S. Reid (1993). Post harvest physiology and handling of fresh culinary herbs. J. Herbs, Spices \& Medicinal Plants 1(3): 93-127.

Chiej, R. (1984). The Macdonald Encyclopedia of Medicinal Plants. Macdonald \& Co. (Publishers) Ltd. P. 264.

Egyptian Pharmacopoeia (1984). Egyptian Pharmacopoeia, General Organization for Governmental. Printing office, Ministry of Health, Egypt. 31-33.

Giese, J. (1994): Use of flavors in food. Food Technology, p.106 -108.

Gomez, E.J.; M. Guerero and B. Bracho (1999). Postharvest performance of coriander (Coriandrum sativum L.) under refrigeration. Revista de Agronomia, Universi dad delzulia 146-150 (Hort. Abst., 70(4): 3514).

Gomez, K.A. and A.A. Gomez (1984). Statistical procedures, Res. 2nd Ed. John Wiley and Sons, Inc., New York, USA.

Guenther, Z. and Joseph, S. (1978): Handbook Series in Chromatography CRC press, Inc., USA.

Joyce, D. and M. Reid (1986). Post harvest handling of fresh culinary herbs. The Herb, Spice, and Medicinal Plant Digest. 4(2): 1-7. 
Karwowska, K. (1997). Influence of storage methods of fresh basil (Ocimum basilicum L.) and tarragon (Artemisia dracunculus L.) on their quality. J. Hort. Sci., 18: 127-139.

Keville, K. (1999). Herbs "An Illustrated Encyclopedia" Michael Friedman Publishing Group Inc. p. 167-168.

Kmiecik, W.; Z. Lisiewska and G. Jaworska (2001). Effect of storage conditions on the technological value of dill (Anethum graveolens L.). Folia Hort. 13(1): 33-43.

Lamberti, M. and F. Escher (2007). Aluminium foil as a food packaging material in comparison with other materials, Food Reviews international,Vol.23(4): 407- 433.

Mae, J. (2004). The occasional gourmet, why fresh and spice is better spice. POBOX 29355, San Francisco, CA, 94/29-0355, by Eleaders.

Paakkonen, K.; T. Malmsten and L. Hyvonen (1990). Drying, packaging and storage effects on quality of basil, majoram and wild marjoram. J. Food Science, 55(5): 1373-1377

Panda, H. (2000). Essential Oil Hand Book. Published by National Institute of Industrial Research, Delhi, India. p. 73-86.

Rashed, Nahed, M. M. (2002). Effect of fertilization on the growth and storability of some aromatic plants. M.Sc. Thesis, Fac. Agric., Kafr ELSheikh, Tanta Univ.

Singh, A. K.; A. A. Naqui; G. Ram and S. Kamla (1994). Effect of hay storage on oil yield and quality in three Cymbopogon species (C. winterianus, C. martini and C. flexuosus) during different harvesting seasons. J. Essential Oil Research, 6(3): 289 - 294.

Tomkins, B. and A. Chennell (2000). Storing and Handling culinary herbs. Institute for Horticultural Development, Victoria Rural Industries Research of Development Corporation. 65.

Xuetong, F. and K.J.B. Sokorai (2002): Changes in volatile compounds of $\mathrm{Y}$-irraadiated fresh cilantro leaves during cold storage. J. Agric.Food Chemistry. 50:7622-7626.

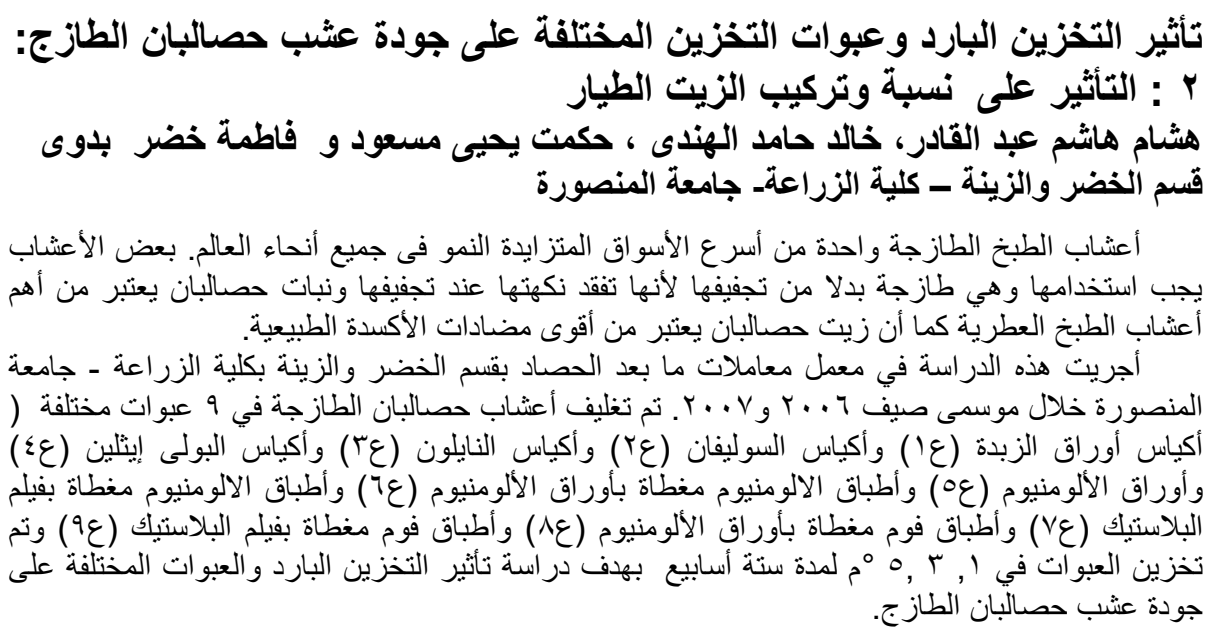


وفي هذا الجزء (r) هدفت الدراسة إلى دراسة تأثير التخزين البارد والعبوات المختلفة على نسبة

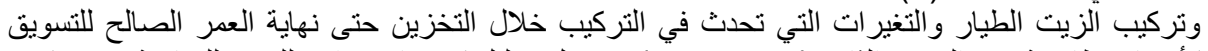

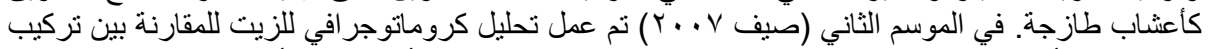

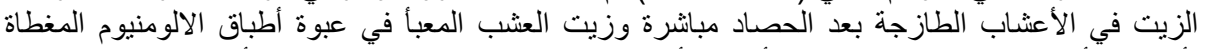

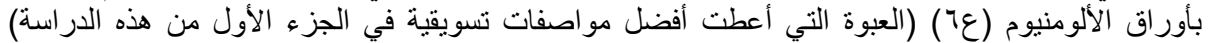

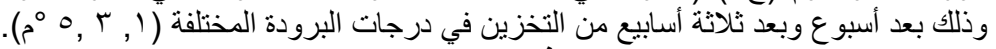

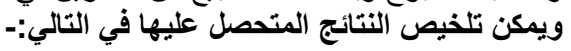

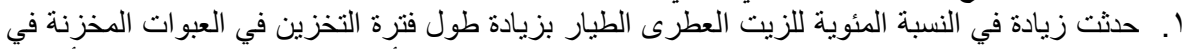

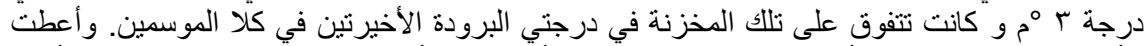

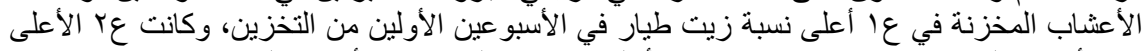

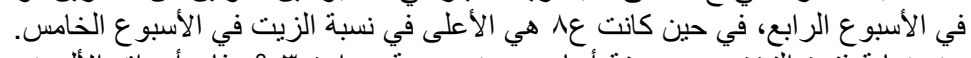

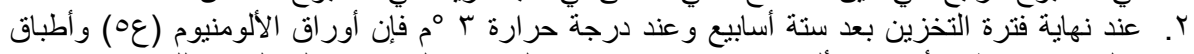

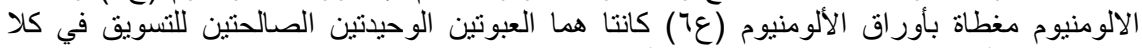

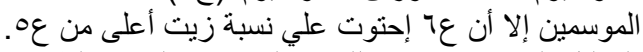

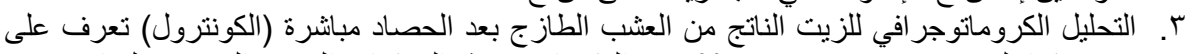

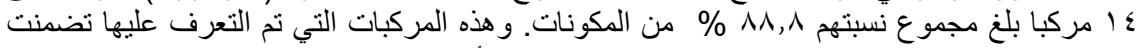

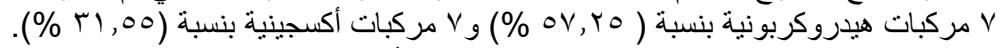

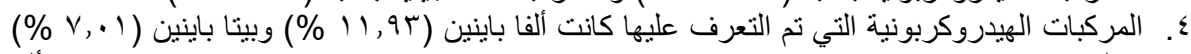

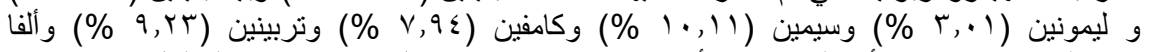

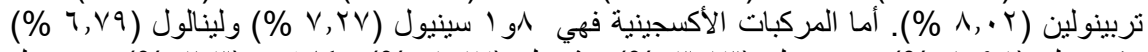

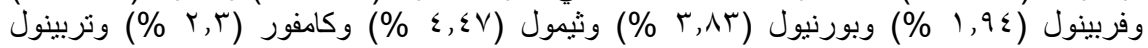

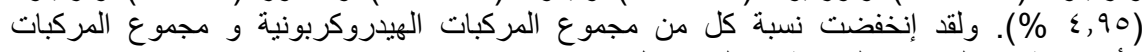

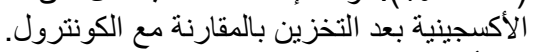

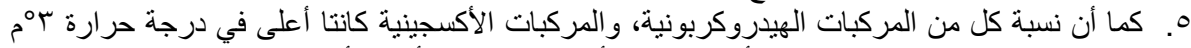

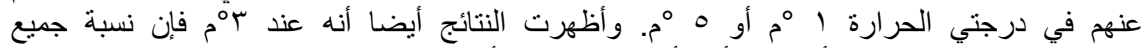

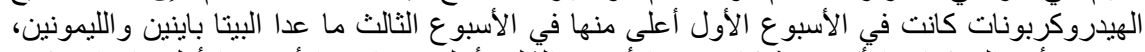

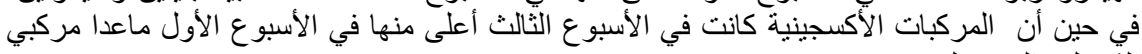

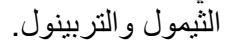

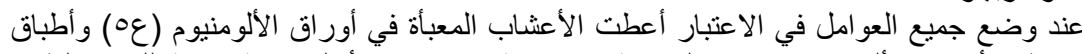

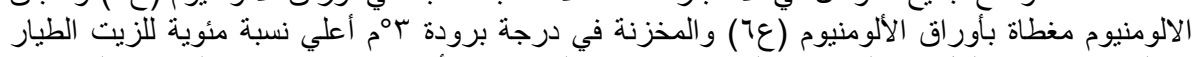

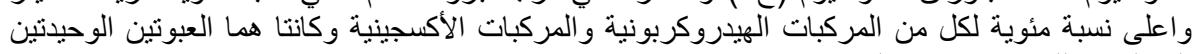
الصالحتين للتسويق في كلا الموسمين.

كلية الزراعة - جامعة المنصورة كلية الزراعة - جامعة الأسكندرية

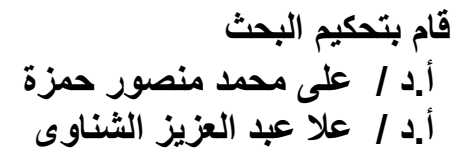

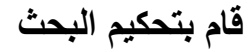
أ. أد / علا عبد العزيز الثناوى منصور 